\title{
ANALYSIS OF VALUE STREAM MAPPING AND LEAN SYSTEM APPLICATION TO IMPROVE TENDER CREATING PROCESS: A CASE STUDY IN PT XYZ INDONESIA
}

\author{
Akbar Rachman \\ Master of Business Administration \\ Faculty of Business Administration and Humanities \\ Swiss German University, Indonesia
}

\begin{abstract}
PT XYZ Indonesia, established in 1986, is a US-based oil and gas service company who provides services from drilling and evaluation, to completion and production. As a service company with huge amount field projects, its Business Development division is a spearhead for the company's growth. Over the years, the competition is getting tougher with many local companies, besides other new international service companies, are penetrating the Indonesia's market. PT XYZ Indonesia have been utilizing the same procedure and process map to develop its business strategy, win tenders, execute field projects, and ultimately expand its operation. The purpose of this research is to analyze the current process of tender creation; identify the challenges the company has been having to win more projects, and eventually provide an improvement to the current-state map. The qualitative research was done by having field observations, conducting interviews, and analyzing secondary data, to reveal the issues at hand. The results show that PT XYZ Indonesia, especially its Business Development division, is not utilizing its resources to full capacity by not managing it efficiently - especially in forms of administration and workforce. In conclusion, a set of recommendations to improve the tender creating process specifically, and its Business Development strategy generally, were formulated.
\end{abstract}

Keywords: Business Development, Tender Proposal, Value Stream Mapping, Lean System 


\section{INTRODUCTION}

$\mathrm{H}$ ich comprises of various energy industry; petroleum, gas, electrical power, coal, nuclear, traditional and renewable energy; is developing massively at least for the past 20 years.

Why is energy industry crucial? Managing the utilization of energy is inevitable in any functional society. In most industrialized countries, the exploitation and development of energy resources are essential for aspects such as, agriculture, transportation, waste collection, information technology and communications - which has become the prerequisites of a developed society. Mankind has been inventing devices, or machines, to more exploited the potential use of energy. This trend is the same way in any other field of social activity. It can be safe to say, that energy industry is what has created the world to be in the current state.

Why is it important to manage the utilization of energy? The increased use of energy utilization since the emerging of Industrial Revolution has also brought in some serious environmental issues, such as the global warming. Most parts of the energy industry generate considerable pollution, including toxic and greenhouses gases from fuel combustion, nuclear waste, and oil spillages, for example. Many electric power plants burn coal, oil, natural gas in order to generate electricity for energy needs. Burning fossil fuels for electricity generation also releases heavy metal matters such as beryllium, cadmium, chromium, copper, manganese, mercury, nickel, and silver into the environment; which mostly act as pollutants (Tchounwou,
Yedjou, Patlolla, \& Sutton, 2012).

The world leaders felt the urge to regulate the energy exploitation and utilization, limiting and supervising the energy management; one of the effort was signing the

Kyoto Protocol back in 1997. The Kyoto Protocol in an international treaty that commits its members to reduce greenhouse gas emissions (UNFCCC, 2005).

Among all the energy resources stated, while almost all the non-renewable energy posed the similar threats, oil and gas are the ones massively used around the world. In 2007, The Energy Information Administration estimates that primary sources of energy consisted of petroleum $36.0 \%$, coal $27.4 \%$, and natural gas $23.0 \%$; they were totaling up to $86 \%$ share in primary energy consumption in the world. Adding to the statement, it's estimated the world energy consumption was growing averagely $2.3 \%$ per year.

Crude oil and natural gas have been a commodity since late $1950 \mathrm{~s}$, replacing coal. Nowadays, about $90 \%$ of fuel needs are met by oil. Generally, petroleum's worth as a portable, dense energy source, powering the vast majority machines and vehicles; and as the base of many industries; makes it one of the world's most important commodities. Organization of Petroleum Exporting Countries is coordinating and unifying the petroleum policies among the petroleum exporting countries in order to secure fair and stable prices for petroleum producers. 
Figure 1. OPEC share of world crude oil reserves

OPEC share of world crude oil reserves, 2015

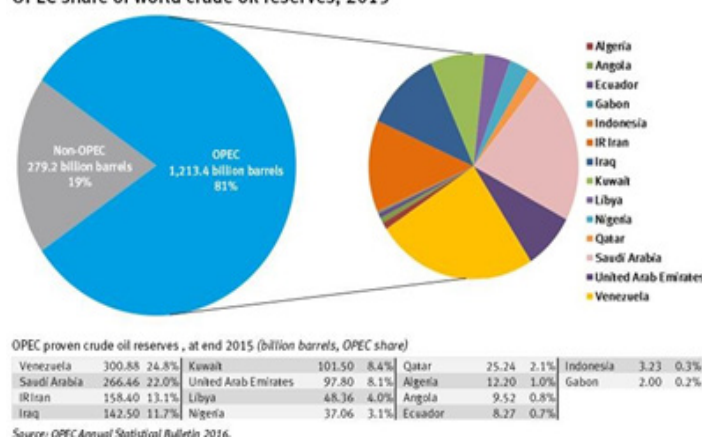

Due to the nature of oil and gas business, which consists of high technology and complex engineering specification, also include a huge amount of both government and contractors' fund, BPMIGAS (currently SKK MIGAS) has regulated the tendering and contract process to minimize risk of losses.

SKK MIGAS and Ministry of Energy and Mineral Resources developed PTK (Pedoman Tata Kerja) which consists of regulated bidding process between the governments, the oil and gas companies, and their contractors/sub-contractors (SKK MIGAS, 2016).

PTK (Pedoman Tata Kerja) (SKK MIGAS, 2016) acts as guidelines for every bidding process for oil and gas business sector. As a result of following the guidelines, any company would then issue a tender with high specification and complex requirements. This, will make bidding process, especially creating tender document is a very challenging task.

The failed or disqualified tenders also mean losing opportunities for the company, and the evidences can be examined from below list;

- Tender disqualification due to mistakes in commercial format (16/06/14) Losses \$362,047.17

- Tender disqualification due to mistakes in document format $(18 / 05 / 15)$ -
Losses \$2,006,389.83

- Tender disqualification due to legal exception (16/09/15) - Losses $\$ 2,193,260.41$

- Tender disqualification due to technical evaluation (09/09/15) - Losses $\$ 7,960,017.56$

- Tender disqualification due to technical evaluation (10/09/15) - Losses $\$ 1,847,268.11$

Figure 2. PT XYZ Indonesia opportunities losses

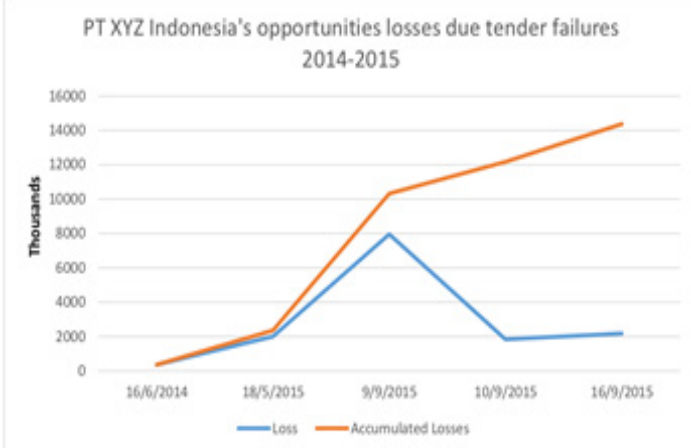

II. LITERATURE REVIEW

\section{II.1.1. ENERGY INDUSTRY IN INDONESIA}

Indonesia's own economic and political development since the Asia regionfinancial crisis and its transition to democracy are signs of significant improvement and a success story. Indonesia has managed to achieve consistently high growth rates over the last 15 years (International Energy Agency, 2015).

There are 2 (two) main energy resources in Indonesia; fossil fuel energy source and renewable energy sources. The fossil fuel energy sources can be harvested from oil, gas, coal, shale, and gas methane; the renewable energy sources include biomass, hydroelectricity, geothermal energy, wind energy and solar power (Dewan Energi Nasional, 2014).

Even so, Indonesia remains a net energy 
exporter. It's the largest coal exporter globally and largest exporter of gas and liquid biofuels regionally. Apart from oil, gas, and its products, Indonesia is energy independent. The development and expansion of coal, palm oil, biomass and other renewable source of energy have helped this process.

\section{II.1.2. OIL AND GAS}

Oil and gas have important roles for economic development in Indonesia. An article in Jakarta Post on May 2012 stated that "...80\% of oil and gas revenues pay for subsidies." (Fadillah, 2012).

On early 1980s, Indonesia was a significant oil-exporting country. Within

Indonesia territory, there are considerable amounts of oil and gas in Sumatra, Kalimantan, Java, and Papua Barat.

Nonetheless, amid diminishing of oil and gas reserves, and production, Indonesia is increasingly dependent on imported oil supplies and become the second-largest oil importer in Asia.

\footnotetext{
Key data (2012)

Crude oil production: 42.6 Mtoe, $-30.6 \%$ since 2002

Crude oil net imports: 1.9 Mtoe

Oil products net exports: 28.6 Mtoe

Share of oil: $36.1 \%$ of TPES and $16.7 \%$ of electricity generation

Consumption: 77.2 Mtoe (transport 50.9\%, residential 15.1\%, industry 14.4\%, power generation 10.7\%, commercial and other services $8.8 \%$ )

Figure 3. Indonesia's crude oil production 2012 Source: International Energy Agency, 2015

Key data (2013 estimated)

Production: 78.8 bcm,$+1 \%$ since 2003

Exports: $34.8 \mathrm{bcm},-17.8 \%$ since 2003

Share of gas (2012): $16.4 \%$ of TPES and 23.2\% of electricity generation

Consumption by sector (2012): 39.2 bcm (industry 48.7\%, power generation 29.5\%, other transformations $21 \%$, commercial $0.6 \%$, residential $0.1 \%$, transport $0.1 \%$

Figure 4. Indonesia's crude oil production 2013 Source: International Energy Agency, 2015
}

Based on above figures, courtesy of International Energy Agency, Indonesia's crude oil production has been reduced as much as $30.6 \%$ in 2012 , and its gas exports has diminished as much as $17.8 \%$ in 2012. Both data have been taken since 2002 and 2003, respectively.

\section{II.1.3. BPMIGAS AND SKK MIGAS} BPMIGAS (Badan Pelaksana Kegiatan Usaha Hulu Minyak dan Gas Bumi) is a government body that acted as a government representative, a guide and also as a supervisor of KKKS (Kontraktor Kontrak Kerja Sama, or Cooperative Contract Contractors) - as main operators in running exploration, exploitation, and marketing activities of oil and gas in Indonesia. This institution was established on July 2002 based on UU no.22/2001 and PP no.42/2002.

BPMIGAS roles (SKK MIGAS, 2016) include;

- Maintaining relationship in order to achieve integration and synchronization in KKKS operational activities

- Generating policies based on KKKS work programs and funding

- Supervising KKKS main activities

- Maintaining state-owned KKKS assets

The institution was finally disbanded on November 2012, and was replaced with SKK MIGAS (Satuan Kerja Khusus Pelaksana Kegiatan Usaha Hulu Minyak dan Gas Bumi).

\section{II.1.4. PTK 007}

PTK (Pedoman Tata Kerja) is a series of regulation and policies drafted by SKK MIGAS to administer all activities related to oil and gas EPC in Indonesia. As one of the PTK include, the PTK 007 solely act as a guideline to all supply chain and procurement activities between KKKS 
and its contractors.

Below are the list of PTK 007 and its revisions;

- PTK 0072004 Pengelolaan Rantai Suplai KKKS

- PTK 007 Revisi-I 2009 Pengelolaan Rantai Suplai KKKS

- PTK 007 Revisi-II 2011 Pengelolaan Rantai Suplai KKKS

- PTK 007 Revisi-III 2015 Pengelolaan Rantai Suplai KKKS

\section{II.1.5. BIDDING AND TENDERING PROCESS}

Bidding and tendering process for oil and gas sector in Indonesia can visualized in below figure;

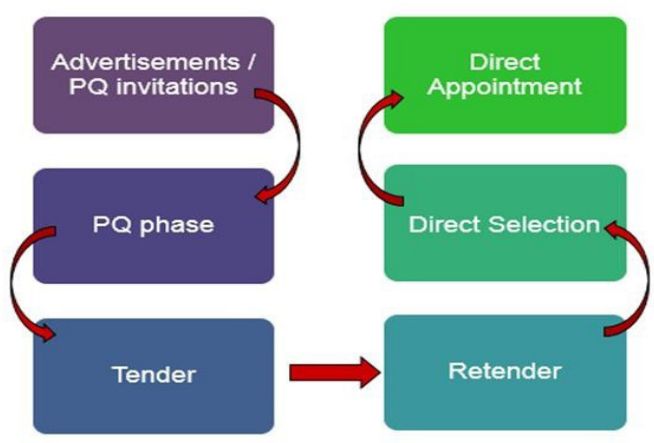

Figure 5. PT XYZ Indonesia Tendering Process Source: Researcher's own elaboration, 2016

From above figure can be described as follows;

Once a client decided to issue a tender, an advertisement comes out to announce the news of the tender, or the client already know who will be the bidders and send them the invitation to bid directly. This is indirectly explained to link and differences between a "client" and a "company/ bidder".

A prequalification phase is a first step to filter out the bidders, so only the capable ones may participate in the tender. Once a bidder passed the prequalification phase, it will get an invitation to bid and allowed to buy the tender document.

After the tender has been submitted by a bidder, then the client will evaluate the administrative, technical, and commercial aspects of the bidder's tender document, based on parameters set up by PTK 007 and client's own requirements. If it passes, and also proved to be the bidder with the lowest price offered, then it will win the tender.

If the bidders registered and attended the pre-bid meeting are less than 3 (three) bidders, then the tender will be failed (SKK MIGAS, 2015), and the client will need to issue a retender. The process also already cover the possibilities whether the retender is also be failed, then the next phase is will be a direct selection, and then direct award.

\section{II.1.6. DOCUMENT MANAGEMENT SYSTEM}

Document Management System-DMS (AIIM, 2016) is the utilization of a computer system and/or software system to store, manage, and track electronic documents and images of paper based information. It's how the organization stores, manages, and tracks its document.

According to ISO 12651-2, a document is a recorded information or object which can be treated as a unit. The DMS incorporates document and content capture, workflow, document repositories, COLD/ERM, output systems, and information retrieval systems. Also, the processes include tracking, storing, and controlling documents.

The DMS is one of the precursor technologies to content management, and not all that long ago was available solely on a stand-alone basis like its imaging, workflow, and archiving brethren. It provides some of the most basic 
functionality to content management, imposing controls and management capabilities onto otherwise general documents.

Some of the main features in DMS include;

- Check-in/check-out and locking, to coordinate the simultaneous editing of a document so one person's changes don't overwrite another'sVersion control, so tabs can be kept on how the current document came to be, and how it differs from the versions that came before.

- Roll-back, to activate a prior version in case of an error or premature release.

- Audit trail, to permit the reconstruction of who did what to a document during the course of its life in the system.

The DMS eventually was subsumed into content management in no small measure because there is more information available today than ever before, and most of it is not being created by the organization itself. Today, the DMS range in size and scope from small, standalone systems to large scale enterprise-wide configurations serving a global audience. Many DMS provide a means to incorporate standard physical document filing practices electronically. These include such as;

- Storage location

- Security and access control

- Version control

- Audit trails

- Check-in/check-out and document lockdown

\section{II.1.7. OPERATION MANAGEMENT}

Operation management is referring to the administration of business practices to create the best level of efficiency possible within an organization. It is focused with converting raw materials and workforces into goods and services, as efficiently as possible, to maximize the profit (Investopedia.com, 2017).

According the US Department of Education, the field study of operation management is focused with managing and directing the physical and/or technical functions of an organization, particularly relates to product development, production, and manufacturing (IES NCES, 2017).

In 1959, Friedrick Klemm stated that the history of this study has stretched back from 5000 B.C., when Sumerian priests developed ancient system to record inventories, loans, taxes, and business transactions. Major applications of this system utilization include the planning, organization, and control of the pyramids in 1100 B.C. (Wren \& Bedeian, 2009).

Lean system, which includes manufacturing and services, is one of the integral in operation management study. This particular production approach is aimed to reduce wastes in processes. Some elements are also fundamental, such as; production smoothing, capacity buffers, setup reduction, cross-training and plant layout (Hopp \& Spearman, 2011). Besides wastes reduction/elimination, Value Stream Mapping is one of the tools that is utilized in this production system.

\section{II.1.8. VALUE STREAM MAPPING}

Value Stream Mapping is a representation of process flow, mostly use to describe the process from manufacturer or supplier to customer. It's one of the lean-management method that enables us to trace delays or restraints in the process. Eventually, this method will help analyzing current condition, and to design a better future 
condition.

Value Stream Mapping has supporting tools that are often used in Lean-utilized environments to analyze and design process flow. Not only associated with manufacturing, Value Stream Mapping also can be utilized in service related industries. Keyte and Locher in their book The Complete Lean Enterprise (2016) stated that the real challenge of applying Value Stream Mapping in service related industries is to be creative enough to figure out how to use them best to align work processes with customer's expectations and make the lives of the staff a bit easier from day to day (Keyte \& Locher, 2016).

Womack and Jones also defined, in their book Lean Thinking (1996), that the set of all specific actions required to bring a specific product or service through the 3 critical management tasks of any business (Womack \& Jones, 1996);

1. Problem solving

2. Information management

3. Physical transformationValue Stream Mapping can identify continued opportunities to enhance value, eliminate waste, and improve work flow; but it's not the end but the beginning of the transition in Value Stream Management.

\section{II.1.9. LEAN SYSTEM}

According to Don Tapping and Tom Shuker in Value Stream Management for The Lean Office (2003); lean system is one in which people strive to eliminate non-value- adding activities, or waste.

The key concepts in understanding lean are (Tapping, Luyster, \& Shuker, 2003):

- The cost reduction principle

- The seven deadly wastes
- Just-in-time

- Three phases of lean application

- Total employee involvement

- The visual office

\section{II.1.9.1. THE COST REDUCTION PRINCIPLE}

Traditional management thinking states that company set selling price by calculating cost and adding on a margin of profit. Lean evolved out of Toyota's cost reduction philosophy. In that approach, market conditions set the selling price, and cost and profit become variables. The primary focus will be on internal costs.

By using the cost reduction approach, company determines the price customers are willing to pay and subtract the cost to determine the profit at that cost level. The lean way of thinking forces company to reduce costs within the organization to ensure profit

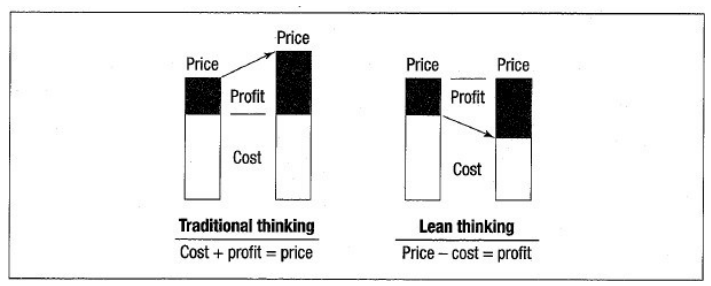

Figure 6. Cost Plus versus Price Minus Source: Value Stream Management for the Lean Office, 2003

\section{II.1.9.2. THE SEVEN DEADLY WASTES}

The ultimate lean target is the total elimination of waste. In lean terms, waste is anything that adds cost or time without adding value. It is something being done that has no value, even though it may be included in the overall cost.

Waste is categorized into seven different types. Each can be targeted specifically to help identify the appropriate lean tool to assist in its elimination. Waste is even more of a problem in the office. 
A disorganized, wasteful environment exacts a heavy toll on people. It keeps them from being and feeling successful. The wastes are also known as the seven deadly wastes because they are like toxins in the work environment.

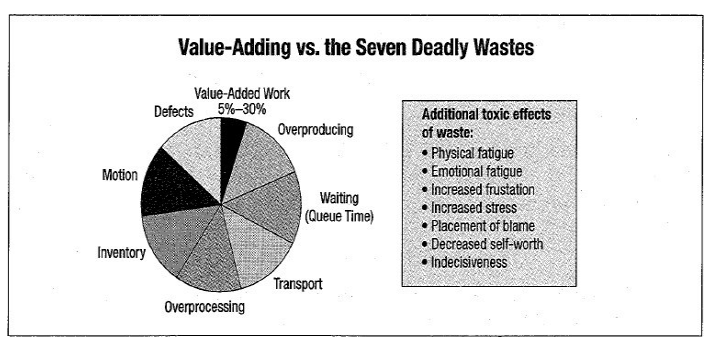

Figure 7. Value Adding vs the Seven Deadly Wastes Source: Value Stream Management for the Lean Office, 2003

\section{II.1.9.3. JUST-IN-TIME}

Just-in-time is at the heart of the lean system because it ensures that the next stream process has; only those work units needed, just when they are needed, and in the exact amount needed.

The ideal state is characterized by the ability to replenish a single work unit when the customer has pulled it. This ideal state is also commonly known as the "pull system", the opposite of the "push system" - common in most workplaces, in which work piles up in batches as it is pushed from process to process.

In the office, the flow of various types of work units as well as information is one of the main concerns. Applying lean principles in the office process means learning to see the flow of business processes in terms of units of work or information.

\section{II.1.9.4. THREE PHASES OF LEAN APPLICATION}

The three phases of lean application are customer demand, continuous flow, and leveling. Understanding the demand flow, and leveling phases of application, along with the guidelines for implementing the
VSM (Value Stream Mapping) process, will provide user with the solid approach required, not only for implementing but also for sustaining lean improvements.

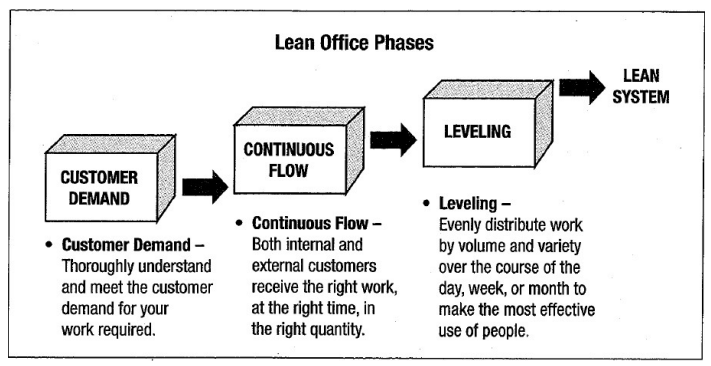

Figure 8. Three Phases of Lean Application Source: Value Stream Management for the Lean Office, 2003

\section{II.1.9.5. TOTAL EMPLOYEE INVOLVEMENT}

In a lean system the foundation for everything begins with philosophy about people. Employees should be encouraged to make positive contributions to improve their own work areas. Additionally, through kaizen events, teams meet for a short period to analyze a problem, recommend an improvement activity, and make it happen, allowing continuous improvement ideas to become a reality.

\section{II.1.9.6. THE VISUAL OFFICE}

The goal of the visual office is to give people control of the workplace. The visual office contributes to total employee involvement. It entails such actions;

- A designated place to share improvement ideas that is common to the area.

- A system to maintain visual standards and levels of housekeeping (a 5S program)

- A small team that is rotated on a regular basis to continually improve.

\section{II.2. PAST RESEARCHES II.2.1. JOURNAL}

Nowadays, the document management system in almost all organization are 
developed into an integrated digital format. The system development is different in every organization, based on their own specific needs.

A previous study showed that any organization, in public or private sector, deals with large amounts of different documents on daily basis; tender proposal and contract document in the current case. An institution has sooner or later come to a decision about the integration of document management system to other information systems (IS) (Leikums, 2012).In conclusion;

- Integration of DMS is mandatory for;

o Finance management system

o Human Resource management system

o Workflow system

- Integration of DMS is advisable for;

o $\mathrm{AD}$ or its analogue

o Customer Relationship Management system

- Integration of DMS is optional for;

o Geographic information system

o Office software

o ERP

o Web portal

It can be seen from above categories that integration of DMS in business development workflow can be categorized as mandatory, or advisable (at PT XYZ, CRM operates under BD division; the same as tender proposal and contract document).

\section{II.2.2. NON-JOURNAL}

There are factors that affect the selection criteria of a DMS, such as;

- The system must be highly flexible.
It must have the ability to adapt to changing requirements. This flexibility needs to extend to specific industries and various environment.

- The system must be able to accommodate individual work styles. Every organization or workgroup has its own way of processing documents and images, and while a new application may provide an opportunity for change, it shouldn't mandate it.

Developing a capable, flexible DMS will make the difference between efficient and functional retrieval, particularly as the system becomes bigger and more complex (Davis, Anderson, \& Cobb, 1998). Additionally, there are key attributes for a good DMS (Selvi, Khan, \& al, 2011), such as;

- Capture

The capture of documents in different file formats and importing into a document management system.

- Storage

In DMS, the files are stored centrally either in a database or in a file storage server with ardware redundancy with good storage capacity to accommodate future requirements.

- Indexing

Documents are indexed for easy and flexible retrieval.

- Retrieval

Retrieval process utilizing index system.

\section{- Access}

Provide authorized access for security purposes. Generally, not every person in the organization may have direct access to tender proposal and contract documents as they are hugely considered as corporate secrets. 
Below figure simply describe the general flow of DMS utilization in an organization

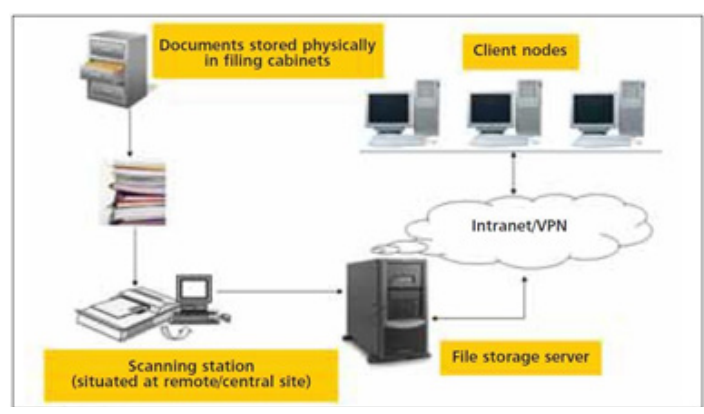

Figure 9. Ideal Document Management System Source: Steel Times International, 2015.

\section{METHODOLOGY}

The main method that will be used in this research is qualitative. The method enables researcher to review current process, secondary data gathered, field observation, and interviews to reveal the issues.

The data will show the entire tender that the company has been participating since 2013. The bid number is the document identity; each tender package has one bid number. The issues column stated that whether one particular tender had any issues during the proposal making process; for example, "technical" means the tender had issues with technical requirements in the process and possibly during technical evaluation by the bid committee, the same goes with "commercial".

The table below is a description on how the data will be displayed, based on above explanations.

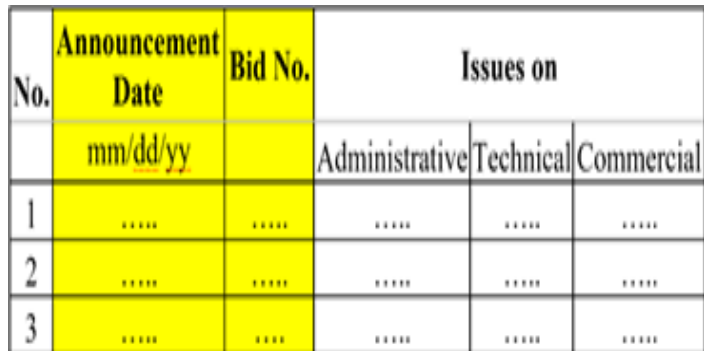

Table 1. List of Project Data Template Source: Researcher's own elaboration, 2016.

\section{III.1. TIME \& PLACE OF RESEARCH}

PT XYZ, Business Development division. The period of research is between 2015 to 2017, utilizing additional secondary data for the past 3 years. The projects themselves are located in various area of Indonesia, yet the data are compiled and stored in Jakarta.

\section{III.1.1. RESEARCH MODEL}

The purpose of this research is to analyze the current tender creating process, identify the challenges occurred, and provide improvement for the process.

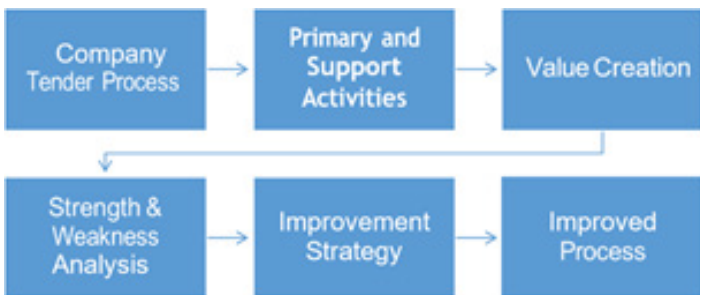

Figure 10. Research Model

Source: Researcher's own elaboration, 2016

The ideal tender creating process consists of 5 primary activities;

\section{Identify Opportunities}

The phase of identifying opportunities. Company (or bidder) is looking out for tender opportunities; it often comes from lobbying activities, formal invitations, or ads in local newspapers.

\section{Tender Registration}

The phase of tender registration. Once company (or bidder) identified the opportunity, the next step is to register so they can participate in the tender process.

\section{Tender Review}

The phase of tender review. Once registered, company (or bidder) will identify the project scope of work and profitability; and then decide whether to continue to participate in the bidding process or not. 


\section{Tender Development}

The phase of tender development. This phase took up most of the time in the whole tender process. The phase includes administrative, technical, and commercial parts that need to fulfill tender requirements.

\section{Tender Submission \& Opening}

The final phase in tender process is tender submission and opening. The completed tender document is submitted to fulfill client's request.

Based on above primary activities, they are extended into supporting activities, such as described below;

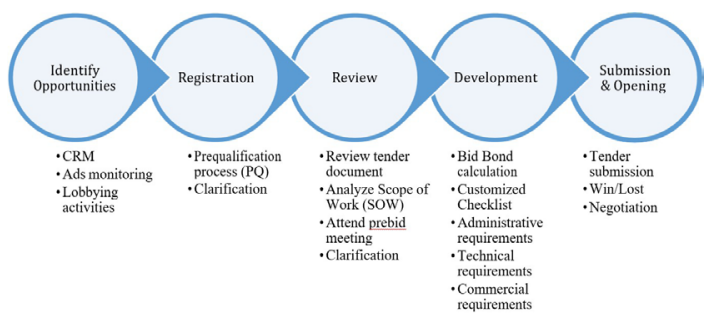

Figure 11. Five Primary Activities

Source: Researcher's own elaboration, 2016

The purpose of this research is to analyze PT XYZ Indonesia's business development workflow, especially its process map and document management system that mainly construct the basis of company's tender creating process. The results will be composed of interviews with company's employees, field observation and data gathering since 2013, and a premiere current-state map. The findings will generate an image of the current state of PT XYZ Indonesia's tender creating process, and will then be discussed and analyzed for possible improvements.

\section{III.1.2. INTERVIEWS}

Interviews were held in PT XYZ Indonesia for a number of employees to gather More detailed perspectives on past and present condition in Business Development division, and gain more knowledge of tender creating process. The interviews are conducted to help answering the following research questions: 2. What are the challenges in the current tender development process? And; 3. How the process can be improved?

The respondents for the interviews are consists of main employees of PT XYZ Indonesia's Business Development division; Business Development Manager, Proposal Manager, Account Representative, Proposal Development Supervisor, Proposal Specialist and Admin.

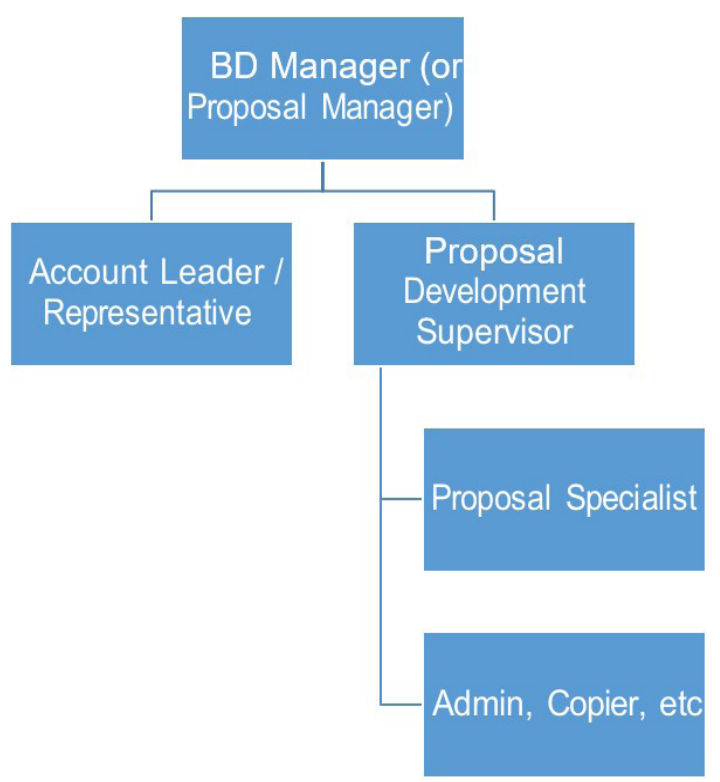

Figure 12. PT XYZ Indonesia's Business Development division

Source: Researcher's own elaboration, 2017

For the verification of interview results, random questions were asked to the employees in the given division to complete the triangulation method of validity.

Interview questions asked consisted of both background questions - to identify employees' position and motive in the company, and problem identification questions

- to identify potential challenges, 
concerns, and possible suggestions from the employees.

\begin{tabular}{|c|l|}
\multicolumn{2}{l}{ Table 2. Interview Questions } \\
\hline \multirow{5}{*}{ Background } & $\begin{array}{l}\text { What is your title and position? } \\
\text { What is your job description? } \\
\text { How does the tender creating process actually work? } \\
\text { What is the current working mechanism? } \\
\text { What kind of standard operating procedure is } \\
\text { implemented? }\end{array}$ \\
\hline \multirow{5}{*}{ Problem } & $\begin{array}{l}\text { Do you think there are challenges or problems in the } \\
\text { tender creating process? } \\
\text { What part of the process is effective? What part is } \\
\text { ineffective? } \\
\text { What are the challenges in implementing the current } \\
\text { process and procedure? } \\
\text { Where in the process stages challenges or problems } \\
\text { often occurred? } \\
\text { What solutions you would suggest to improve the } \\
\text { current condition? }\end{array}$ \\
\hline
\end{tabular}

The interview has been conducted on early 2017 to get the best and most recent responds, and below are the results;

Table 3. Interview Results

\begin{tabular}{|c|c|c|c|c|c|c|c|c|}
\hline \multirow[t]{2}{*}{ No. } & \multirow[t]{2}{*}{ Challenges } & \multicolumn{7}{|c|}{ How many times respondents mentioned the challenges? } \\
\hline & & $\mathrm{R} \# 1$ & R\#2 & $\mathrm{R} \# 3$ & $\mathrm{R} \# 4$ & $\mathrm{R} \# 5$ & R\#6 & $\Sigma$ \\
\hline 1 & $\begin{array}{l}\text { Disruption in } \\
\text { flow of } \\
\text { information }\end{array}$ & $\mathrm{x}$ & $\mathrm{x}$ & & & $\mathrm{x}$ & & 3 \\
\hline 2 & $\begin{array}{l}\text { Keep the process } \\
\text { in check }\end{array}$ & $\mathrm{x}$ & & & $\mathrm{x}$ & & & 2 \\
\hline 3 & $\begin{array}{l}\text { Extensive } \\
\text { workload in } \\
\text { laboratory }\end{array}$ & $\mathrm{x}$ & & $\mathrm{x}$ & & & & 2 \\
\hline 4 & $\begin{array}{l}\text { Shortage of } \\
\text { workforce }\end{array}$ & & $\mathrm{x}$ & $\mathrm{x}$ & $\mathrm{x}$ & $\mathrm{x}$ & $\mathrm{x}$ & 5 \\
\hline 5 & Internal reporting & & & $\mathrm{x}$ & & $\mathrm{x}$ & & 2 \\
\hline 6 & Leadership & & & & $\mathrm{x}$ & $\mathrm{x}$ & $\mathrm{x}$ & 3 \\
\hline 7 & $\begin{array}{l}\text { Disorganized job } \\
\text { distribution }\end{array}$ & & & & $\mathrm{x}$ & $\mathrm{x}$ & $\mathrm{x}$ & 3 \\
\hline 8 & $\begin{array}{l}\text { Document } \\
\text { Management } \\
\text { System } \\
\end{array}$ & & & & $\mathrm{X}$ & & & 1 \\
\hline
\end{tabular}

The results show that "shortage of workforce" was the most concerning challenge in the team and in the process itself (1st rank), and it follows by "disruption in flow information" (2nd), "leadership" (3rd), and "disorganized job distribution" (4th). The complete information of interview results and its detailed responds can be observe in the attachment of this research.

\section{III.1.3. FIELD OBSERVATION AND DATA GATHERING}

In conjunction with the interviews conducted, field observations and data gathering were made to gather more information and understanding on how PT XYZ Indonesia works in its tender creating process. By gaining proper information and knowledge on PT XYZ Indonesia works overall, it is possible to analyze its strengths, weakness, and possible improvements to be made. The observation and data gathering are intended to help answering the research question: 1. How is the current tender development process works?

\begin{tabular}{|c|c|c|c|c|c|}
\hline \multirow[t]{2}{*}{ No. } & Announcement & Bid $N_{0}$ & \multicolumn{3}{|c|}{ Issues on } \\
\hline & $\mathrm{mm} / \mathrm{d} d \mathrm{yy}$ & & Administrative & Technical & Commercial \\
\hline 1 & 10/29/2015 & 099-SERV/RBB/OT/OPS/X/15 & & X & $x$ \\
\hline 2 & 10/9/2015 & CW1401148 & & $x$ & \\
\hline 3 & $9 / 17 / 2015$ & TAK/PTHI/001-PM/VIL/2016 & $X$ & & \\
\hline
\end{tabular}

The complete information of tender projects and its related issues can be observe in the attachment of this research.

\section{III.1.4. APPLYING VALUE STREAM MAPPING AND LEAN SYSTEM PROCESS}

According to Keyte and Locher, Value Stream Management involves a process for measuring, understanding, improving, and managing the flow and interactions of all the associated tasks to keep the cost, service and quality of a company's products and services as competitive as possible. It sets the stage for implementing Lean transformation throughout the whole division, or even the company, and keeps it from falling back and moving backward (Keyte \& Locher, 2016). 
The real purpose of value stream management is all about the ideal mapping. The purpose is to assist a team in visualizing and communicating not only how its organization acts today, but also how it should act in the future to improve performance in terms of the cost, service, and quality of its products and services. The value stream mapping is the first and most important tool for establishing the direction and focus of a Lean transformation.

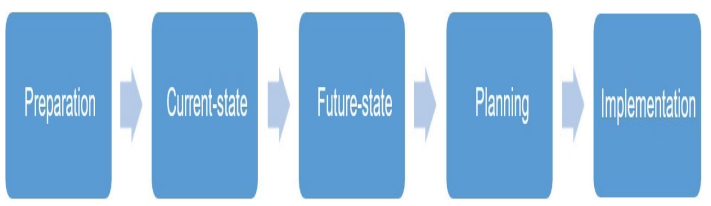

Figure 13. Value Stream Mapping process

Source: The Complete Lean Enterprise, 2016

The current-state map in Table 6 \& 7 provided the present information regarding the actual condition of PT XYZ Indonesia's tender creating process. It took the company approximately 32 days to complete a tender document for the client. By applying value stream mapping in the process, PT XYZ Indonesia will be expected to have shorter process time and a more efficient working team.

From observation and interview findings it can be determined that most of the challenges in the process came from heavy workload in tender development stage, and for some points, lack of leadership and workforce.

Adding parameters from the findings, the future-state map can be determined by recognizing valued activities and reducing wastes.

Keyte and Locher determined 7 questions that must be answered to design ideal future-state map;
1. What does the customer really need?

2. Which steps create value and which generate waste?

3. How can work flow with fewer interruptions?

4. How will interruptions in the flow be controlled?

5. How will the workload and/or activities be leveled?

6 . How will we manage the new process?

7. What process improvements will be necessary to achieve future-state?

\section{What does the customer really need?}

The customers, in this case the clients, requires quick response from the company as a contractor. The clients are also being pushed by SKK MIGAS to commence their projects soon and efficiently. Every request for quotation, budgetary programs, statement letters, and technical clarifications must be completed as soon as possible. Time factor is the most important thing to fulfill clients' expectations. Besides time, the accurate information given by the company to them is also important.

Which steps create value and which generate waste?

Stages such as Tender Review and Tender Development took the longest time to prepare. The other 3 stages such as Identify Opportunity, Registration, and Tender Submission are not determined by the company's capability to create tender, instead it's determine by the client's capability to process their own paper works. Based on the Figure 15 it can be seen that almost all activities generate value, which means the wastes are hidden inside the process. The field observation and interview findings state 
that extra processing and underutilized people are the recognized interruptions in the process.

\section{How can work flow with fewer interruptions?}

In general, poor information and service quality is a common cause of disruptions in the flow process. People tends to return to a prior step to obtain the correct or missing information. Another potential cause of interruption is the number of handoffs in the current-state, and as a result, for some cases it may be desirable to combine steps and have them performed by a single employee to eliminate or at least reduce handoffs. Based on the observation and interview findings, on Tender Review and Tender Development stages, too often people are working on too many things at the same time. The more work occurred in the flow, the longer it will take for any form of work to make its way through.

How will interruptions in the flow be controlled?

By focusing on the challenges in Question 3 , and overcome them, the interruptions in the flow supposed to be able to control. Additionally, there are occasions where the employee might be responsible for other works outside the value stream, or might be away for meetings outside office, hence it makes sense to find a way to smooth the impact of interrupted flow to improve the system performance. The role of Proposal Manager and/or Proposal Development Specialist are expected to prevent or reduce interruptions in the tender creating process.

\section{How will the workload and/or activities be leveled?}

Work typically requires leveling from 2 perspectives; the process and the system.
In tender creating process, the process may refer to the usual tender creating process, while the system may refer to internal reporting process. Both imbalance create serious issues for the value stream as people must make significant adjustments to the daily efforts, and the resulted lead time can get longer than expected. Based on field observation and interview findings, lack of workforce in the team is mainly the challenge.

\section{How will we manage the new process?}

Once the future-state map is completed, the discussions moves to how the new value stream will be managed. If the company designs a system to perform, it will need to check frequently for abnormalities that hinder this performance and then create corrective actions to get the work back on track. Additionally, the transition into a new process requires focus and discipline from every employees involved. A new role to supervise the integration process may be needed.

What process improvements will be necessary to achieve the future-state?

Instead of creating of a long list improvements, the question actually leads to identify those necessary to make the envisioned future-state a reality. Tools and techniques from Lean toolbox are the best examples to make improvements;

1. Standardized work (e.g. standardized work method, tender formats, tender schedule)

2. Layout changes

3. Cross-functional teams (e.g. team built up from PSLs to supervise, or provide inputs)

4. Error-proofing

Additionally, the improvements that 
are planned need to cover the gaps as described below;

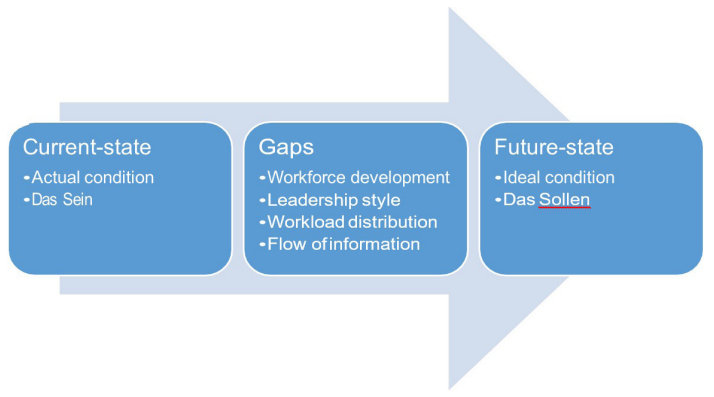

Figure 14. Current state vs Future state

\section{III.1.5. STRENGTH AND WEAKNESS III.1.5.1. STRENGTH}

- The strength of the tender creating process with future-state map lies in the actual former map that only needed to be improved, rather than having the map modified entirely. The Proposal Manager and/or PSL BD Manager need to lay strict rules regarding job descriptions and distribution, and also timing in each process.

- The future-state map also covers the whole tender creating process, from the beginning of identifying opportunities to the very end of tender submission. The same improvements method can also be applied to the next process in the Business Development division, which is "contract creating process"

\section{III.1.5.2. WEAKNESS}

- The future-state map only stream the current process map. It doesn't massively modify the initial process, and respondents have state that this may become another challenge when additional lead time reduction is required.

- The future-state map doesn't enhance the organization's capability to utilize its document management system.

\section{CONCLUSIONS}

Research findings related to its proposed questions conclude the following:

\section{How is the current tender creating process works?}

The current tender creating process includes 5 main activities; identifying opportunities, registration, tender review, tender development, and tender submission. Each of these stages consists of many supporting activities, as has been stated before.

Identifying opportunities stage provide company a project forecasts of what lies out there in the market. In this stage, the company utilize its intelligence in business development skill to gain tender and projects, and increase their market share. Customer Relationship Management (CRM) also holds the key role in mapping market segments and used as preference when developing future business strategy.

Registration stage consists of enroll the company on available tendering processes. The prequalification phase usually precedes everything related to company's administrative, technical, and commercial capabilities.

Tender review stage marks the beginning of an actual tender process. The stage includes reviewing scope of work, attending prebid meeting, corresponding clarifications, and eventually decide whether the company able to participate in the tender process or not.

Tender development stage is a result of tender review's final decision. At this stage, the company starts to fullycreate the 3 main tender document parts; administrative, technical, and commercial. Failure in completing client's requirement in any of those parts will result in 
disqualification for the company.

Tender submission stage is the final step of completing tender creating process. The tender documents are ready to be submitted to the client. The company will send its representatives to attend the bid document opening, and witness the result. Upon determined as a winner, the company will usually leads this process into negotiation, contract award, and then begin a new "contract creating process".

Among the 5 main activities, research concludes that tender review stage and tender development stage took too much time to complete, and dragging the whole process down. The observation and data gathering bear out that the whole process from identifying opportunity until completing and submitting tender usually takes up 33 days; the particular 2 stages in discussion alone consumed around 70\% of the total tender lead time.

\section{What are the challenges in the current tender creating process?}

The field observation and interview findings conclude that there 4 issues and that raise from the present condition and the company's current-state map; the lack of leadership from management, disorganization of the team's job distribution, shortage of workforce, and an inefficient process map. These issues related between one and the other, as has been discussed before.

Most of the senior managers in PT XYZ Indonesia are expatriates and naturally they don't really put too many attention in building a solid team with solid leadership. The managers only stay in the company for up to 3 years due to internal regulation, and with that short working period in between, the managers tend to just focusing on how to increase revenue, and an idea or a concept of building a solid team with solid leadership for the future generation is often neglected.

This issue affected the team to have their own view on how the company and their organization will develop; more often than not, a non-uniform view. Employees tend to limit their working scope, to avoid additional responsibilities, and even lead to shifting their workloads to other employee. The common disorganized job distribution issue is enhanced by the shortage of workforce, due to the recently decreased oil price.

An inefficient process map is a different kind issue but have the ability to affect and worsen the previous issues as well. Internal reporting and complex tender specification requires an undivided attention from all employees related in the process, hence a good process map that covers these activities is also required.

\section{How the process can be improved?}

Upon completion of the research, it has been concluded that an empowered manager role and value stream mapping with lean values applied can actually put the team in solid motion, and reduce the tender process lead time to 26 days; eliminating $21.1 \%$ of initial time required.

\section{IV.1. RECOMMENDATIONS}

The main challenges found in the research are basically and mainly about individual's competency. The shortage of workforce, the disruption in information flow, leadership and management, and lastly the disorganized job distribution. No matter how much logistics and resources has been put in, it wouldn't bring any improvements for the team as long as there are no competent employees or a manager to allocate them efficiently. Below are the recommendations based on 
the challenges found;

\section{- Value Stream Manager}

The research has concluded that the application of a value stream mapping is needed to make the tender creating process map more efficient and lean. The changes will affect the team's working nature, a role of "value stream manager" is need to safeguard the transition process (Keyte \& Locher, 2016). The position doesn't require another new employee to fill in, but also can accommodate some people that already in the organization, e.g. Proposal Manager, or BD PSL Manager.

- Workforce Performance Evaluation

Employees' performance must be kept monitored from time to time. Companies usually apply key performance indicator (KPI) to evaluate each employees' goals and ability to develop themselves. The same concept can be applied to Business Development division.

\section{- Calendar-based Process Evaluation}

This method of evaluation is specifically designed for Account Representative, to help them in track for each process occurred in the workflow. Once a tender document has been released and distributed internally, a "calendar" with specific dates in it will automatically generated. The dates for specific tasks such as issuing bid bond, drafting customized checklists, ask for legal review and finance review, will be displayed in the calendar. PSL BD Manager, PSL Proposal Development Supervisor and Account Representative have the responsibilities to obey the dates set in the calendar, and to pull things forward before it's piling up on a particular date.

- Workforce Regeneration

PT XYZ Indonesia has been established since 1986, and since then a lot of senior employees have retired. There are several employees that has been over their service years, but still employed and working for the company. Their presence unexpectedly have become one of the challenge for the team, since most of their usual work can't be done like the way they were doing it for so many years. Also the positions they are still hold caused a delay in other employees' promotion and reward. The underutilized people is 1 of the 7 wastes in Lean toolbox which has to be eliminated so the organization may grow.

Additionally, to support the individual's competency, othersolutions are also needed to enhance the team's capability. Below are the recommendations; Document Management System

The Business Development division is heavily related not only on its strategy formulating activities, but also on its document management system. The division housed tender and contract files, company's deed, company's certifications, and other confidential documents, which has been collected since 1986 . The field observation and interview findings also reveal that Proposal Specialist and Admins have trouble to access the conventional computerized document management system. This holdup leads to another type of non- productive time, which also potentially drag down the tender creating process.

An integrated document management system is a system that can stored the documents automatically and creating a database that can be tracked and managed digitally.

\section{- New Process Map}

The research that has been done mostly work and improve the company's tender creating process map. The field observation and interview findings reveal that the tendering process in Indonesia is 
quite different than the other countries, while the guidelines that sets the process map was based on the United States-global standard. Inputs have stated that there are possibilities that PT XYZ Indonesia, due to the difference working nature, may have to create its own process map, specific to accommodate SKK MIGAS requirements.

Initially, the management needs to appoint a "Value Stream Manager" to oversee all transformation from currentstate to future state. The preference of the managerial role can be recruited from internal business development team, or appointed from a cross-functional team; which consists of representatives from other PSLs. The manager then will be able to identify which parts of the process is actually the cause of disruption in information flow and disorganized job distribution.

The Value Stream Manager will have the authority to investigate and keep everything in check, including to remind BD Manager and Proposal Manager to keep their employees performance reviewed monthly at the least. The workforce performance evaluation can be re-applied into the play, so each manager may oversee their personnel capabilities throughout every tender project per month.

A calendar-based process evaluation can be applied towards the employees once all managers have clear understanding of their "new" leadership roles. This particular process evaluation will always be generated once every tender document has been received and the process of tender creating will commence; and will always be updated as per every modification from client's requirement. The Value Stream Manager may remind the Proposal Development Supervisor to always keep an eye on these changes, and ask them to always inform their subordinates.

The shortage of workforce is not always about lack of personnel amount in a team, it can also means only a few people actually working and the rest of the employees fall into the underutilized people category. Value Stream Manager needs to make sure that managers aware of this condition, then guide them to apply the KPI annually and set the calendar-based process evaluation for each accounts separately.

Underutilized people divided also affected by huge amount of disorganized job distribution. As discussed previously, managers weren't really notice this issue until a tender project has already failed, and by that time it'd be too late. Only a few people actually working in a full team, because some of them are busy doing jobs they don't supposed to be, or they already are senior employees whose capability cannot be compared with the new hires. Value Stream Manager needs to remind the managers of this situation and start to put each employee in their place. PT XYZ Indonesia has a habit of keeping senior employees which has passed their retirement age limit over 5- 7 years. This is also a waste that needs to be eliminated. By reducing the number of senior employees, the company can develop new hires with new opportunities and new skills. Company also able to freely develop new hires with trainings and certifications related with business development matters. Trainings such as Financial Overview, Business Leadership, and Basic Local Content workshop can be given to the employees annually. Therefore, workforce regeneration is crucial and is a must. 


\section{REFERENCES}

AIIM (2016), What is Document Management System? Retrieved from http://www.aiim.org/What-isDocument-Management

BusinessDictionary.com

NPT. Retrieved from http://www. businessdictionary.com/definition/nonproductive-time.html

Davis, A., Anderson, K., \& Cobb, C. M (1998), How Your Document Management System

Can Grow With Your Company. Work Process Improvement Today Technology Collection.

Dewan Energi Nasional (2014), Outlook Energi Indonesia. Dewan Energi Nasional, Jakarta: Indonesia.

Fadillah, R. D (2012, May), 80 percent of oil and gas revenues pay for subsidies. Retrieved from http://www.thejakartapost.com/ news $/ 2012 / 05 / 21 / 80$-percent-oil-andgas-revenues-pay-subsidies.html

Hopp, W. J., \& Spearman, M. L (2011), Factory Physics. Waveland Press, Illinois: USA.

IES - NCES (2017), Classification of Instructional Programs Operations Management. Retrieved from https://nces.ed.gov/pubs2002/ c ip $2000 /$ o c cupationallookup $6 \mathrm{~d}$. $\mathrm{ASP} ? \mathrm{CIP}=52.0205$

International Energy Agency (2015), Indonesia - Chapter 1 Executive Summary. International Energy Agency, Paris: French.

Investopedia.com (2017), Operation Management. Retrieved from http:// www.investopedia.com/terms/o/ operations-management.asp
Keyte, B., \& Locher, D. A (2016), The Complete Lean Enterprise: Value Stream Mapping for Office and Services. CRC Press New York: USA.

Leikums, T (2012), A Study on Electronic Document Management System Integration Needs in the Public Sector. International Journal of Advances in Engineering \& Technology Vol. 1.

OPEC (2016), Indonesia. Retrieved from http://www.opec.org/opec_web/ en/about_us/3194.htm

Sekaran, U., \& Bougie, R (2014), Research Methods for Business. John Wiley, New York: USA.

Selvi, S., Khan, S., \& al, e (2011), Document Management System - Go green 'a paperless office' for steel plants. Steel Times International, 1-3.

SKK MIGAS (2015), PTK 007. In S. MIGAS, Pedoman Tata Kerja 007. SKK MIGAS, Jakarta: Indonesia.

SKK MIGAS (2016), Pedoman Tata Kerja. Retrieved from http://www. skkmigas.go.id/regulasi-crossposting/ pedoman-tata-kerja-surat-keputusansurat-edaran

SKK MIGAS (2016), Profil. Retrieved from http://www.skkmigas.go.id/ tentang-kami/profil

SKK MIGAS (2016), Profil dan Fungsi. Retrieved from http://www.skkmigas. go.id/tentang-kami/profil

SKK MIGAS (2016), Regulasi. Retrieved fromhttp://www.skkmigas. go.id/regulasi/pedoman-tata-kerja

Stine, R., \& Foster, D (2011), Statistics for Business - Decision Making and Analysis. Pearson, Pennsylvania: USA. 
Tapping, D., Luyster, T., \& Shuker, T (2003), Value Stream Management for the Lean Office: 8 steps to planning, mapping, and sustaining lean improvements in administrative areas. Productivity Press, New York: USA.

Tchounwou, P., Yedjou, C., Patlolla, A., \& Sutton, D (2012), Heavy Metals Toxicity and the Environment. Retrieved from https://www.ncbi.nlm.nih.gov/ pmc/articles/PMC4144270/
UNFCCC (2005), Kyoto Protocol. Retrieved from http://unfccc.int/kyoto_ protocol/items/2830.php

Womack, J. P., \& Jones, D. T (1996), Lean Thinking. Simon \& Schuster, Michigan: USA.

Wren, D. A., \& Bedeian, A. G (2009), The Evolution of Management Thought. Wiley, New York: USA. 